\author{
${ }^{1}$ Carina Tjandradipura dan ${ }^{2}$ Ferlina Sugata \\ Program Studi Desain Interior \\ Universitas Kristen Maranatha \\ 'ctjandradipura@yahoo.com \\ ²ferlina sugata@yahoo.com
}

\title{
REPRESENTASI DAN ORIENTASI SIMBOL PENGHORMATAN DALAM DINAMIKA RUANG IBADAH AGAMA BUDDHA (Studi Kasus: Ruang Ibadah Cetiya di Bandung)
}

\begin{abstract}
Abstrak : Setiap umat beragama pada umumnya memiliki simbol penghormatan untuk memuja keagungan dan kebesaran seseorang yang dianggap sangat penting dalam agama masing-masing. Hal tersebut dilatarbelakangi oleh perkembangan dunia arsitektur dan penyesuaian aktivitas peribadatan berbeda-beda pula sehingga mempengaruhi munculnya tatanan ruang yang beragam pada salah satu ruang ibadah umat agama Buddha yakni cetiya. Dalam perkembangan bentuk ruang cetiya tersebut, aktivitas dalam cetiya ini pun mengalami perubahan yakni sebagai wadah aktivitas ritual dan interaksi keagamaan sehingga memberikan dampak terhadap esensi makna bagi sebuah aktivitas spiritual.
\end{abstract}

Tujuan penelitian ini untuk mengeksplorasi sejarah dan perkembangan bentuk, fungsi dan makna cetiya pada masa awal muncul hingga saat ini, dengan mengidentifikasi tipe cetiya di ranah publik dan privat, dan masih difungsikan sesuai awal terbentuknya namun telah mengalami pergeseran dalam aspek wadah fisik dan kontennya; serta mengetahui sejauh mana terjadi pergeseran tersebut dengan menganalisis faktor-faktor pendorong terjadinya hal tersebut. Metode analisis yang digunakan adalah kajian fenomenologis, yakni mencari faktor pendorong dengan teknik kualitatif rasionalistik sehingga teknik pengolahan datanya merupakan analisis hubungan dari kedua variabel yang dijabarkan menjadi faktor-faktor dan kemudian dilanjutkan dengan menggunakan tabulasi sederhana, sehingga menghasilkan sistematika dari faktor-faktor tersebut.

Pada saat ini cetiya telah mengalami perubahan bentuk menjadi sebuah ruang atau bangunan tempat peribadatan pribadi maupun kelompok tertentu, yakni berupa sudut ruangan atau kamar khusus di sebuah fungsi hunian atau kantor. Pergeseran fungsi yang kini terjadi, tidak memberikan pengaruh signifikan terhadap penataan pola ruang dan tetap dapat memperlihatkan representasi simbol Buddha dengan orientasi ruang memusat serta tetap terjaganya hierarki sebagai ruang ibadah privat dan khusuk walaupun dengan elemen pelingkup dan atribut ruang yang berlainan. Berdasarkan hasil temuan penelitian tersebut, maka dapat disimpulkan bahwa simbol masih dikenal hingga saat ini namun direpresentasikan secara berbeda dari konsep awalnya yang berupa tempat suci atau penyimpanan benda suci Buddha. Penggunaan nama masih tetap digunakan dan fungsi cetiya sebagai ruang ibadah yang menampung aktivitas penghormatan pun masih dipertahankan.

Kata Kunci: Buddha, Cetiya, Orientasi, Representasi, Ruang ibadah

\begin{abstract}
Every religious person basically has their respected symbols to uphold and reinforce the greatness and importance of what they call 'god' of their own religion. This reality occurs as a result of the architecture advancement and the adjustment of activities that are various, which in this case, particularly gives an influential effect on the room design of a Buddhist temple called cetiya. In the particular design, the development design changes the ritual activities, the religious experience and the essence of the religious activities.
\end{abstract}

The purpose of this research is to explore the history and the development of the shape, function and meaning of cetiya from the initial beginning to the current time. This is materialized through the identification of the type of cetiya for private and public. Cetiya also still maintains its origin while simultaneously having some changes on 
its physic and content whose cause is yet to be analysed further in terms of the factors. The method for the analysis is a phenomenological study conducted through searching for the supportive factors by making use of the rationalistic qualitative technique so as to make the data analysis reflect the connection of two variables defined to be factors and elaborated further using a simple tabulation to make it systematic.

At the present time, cetiya has had certain changes into becoming a room or space for private and communal religious rituals, realized in the form of a corner room or a special room that functions as a dwelling place or an office. The alteration of the function gives little significance to the arrangement of the room yet still reflects the symbol representation of Buddhism along with the maintenance of the room orientation and the hierarchy of the private sacred place despite the covering and attributes of the room being relatively different from one another. Based on the findings, it can be summed up that symbols are still known till the present time yet they are represented distinctively from the initial concept, i.e. as a sacred place and safety place for sacred items of the Buddhists. The name is also still used and functioned as well as maintained as a sacred place to honor and praise their gods.

Keywords: Buddha, Cetiya, Orientation, Representation, sacred place

\section{Pendahuluan}

Setiap umat beragama pada umumnya memiliki simbol penghormatan untuk memuja dan memuji keagungan dan kebesaran seseorang yang dianggap sangat penting dalam agama masing-masing. Munculnya beragam bentuk, fungsi dan skala ruang ibadah yang turut disertai beragam aktivitas turut memberi dampak pada perubahan makna sebagai representasi dan orientasi peribadatan. Namun motivasi penghormatan tersebut biasa dilatarbelakangi oleh tradisi dan sejarah serta perkembangan agama yang berbeda-beda serta aktivitas peribadatan yang berbeda-beda pula di setiap lokasi di lain negara. Hal inilah yang mempengaruhi munculnya berbagai ragam desain ruang cetiya sebagai salah satu ruang ibadah umat agama Buddha.

Cetiya adalah bentuk ruang peribadatan terkecil dalam agama Buddha, sesudah Arama dan Vihara. Cetiya muncul sebagai pengganti simbol penghormatan baru setelah jaman Buddha Gautama mangkat pada tahun 543 Sebelum Masehi di Kusinara, India. Dalam perkembangannya cetiya yang terdiri dari empat jenis, yaitu Dhätucetiya, Paribhogacetiya, Dhammacetiya, Uddesikacetiya. Dhätucetiya dikenal juga dengan nama Buddhasārīrikacetiya, sārīrikacetiya, atau relik Sang Buddha dalam bahasa sehari-hari. Dalam perkembangannya beberapa situs berupa cetiya tersebut mulai punah dan lokasinya mulai sulit ditempuh, sehingga muncul jenis cetiya lainnya yaitu Dhammacetiya, berupa bangunan yang menyemayamkan sabda Buddha dalam bentuk bangunan simbolik. Jenis yang terakhir adalah Uddesikacetiya.

Selain empat jenis cetiya tersebut, saat ini istilah cetiya kita temukan dalam bentuk lain, yaitu berupa ruangan kecil yang dijadikan tempat peribadatan pribadi maupun kelompok tertentu, atau suatu komunitas tertentu. Aktivitas dalam cetiya ini pun mengalami perubahan, bukan sebagai simbol penghormatan saja, namun sebagai wadah aktivitas seputar ritual dan interaksi keagamaan. Keberadaan cetiya di Bandung pada saat ini sangat terbatas dan jarang ditemukan, maka dari itu diambil dua buah studi kasus yang sekiranya dapat merepresentasikan dan diidentifikasikan perubahannya yakni cetiya pada bangunan publik yang berada di sebuah perusahaan pada kawasan industri dan cetiya pada bangunan hunian yang dibangun secara khusus. 
Pergeseran ini seyogyanya memberi dampak terhadap esensi makna bagi sebuah aktivitas spiritual, namun sejauh mana terjadinya pergeseran dalam aspek representasi dan orientasi simbol penghormatan tersebut yang akan diteliti serta apa saja yang turut mendorong perubahan tipe-tipe cetiya tersebut di atas. Penelitian ini difokuskan pada berbagai ruangan dan bangunan yang saat ini dinamakan sebagai cetiya sebagai kesepakatan bersama dengan tujuan untuk mengeksplorasi sejarah dan perkembangan bentuk, fungsi dan makna Cetiya pada masa awal muncul hingga saat ini; mengidentifikasi beragam tipe Cetiya yang masih difungsikan sesuai awal terbentuknya serta yang sudah mengalami pergeseran dalam aspek wadah fisik dan kontennya; serta mengetahui sejauh mana terjadi pergeseran orientasi simbol.

\section{Kajian Literatur}

\subsection{Cetiya sebagai Salah Satu Sarana Puja Bakti dalam Agama Buddha}

Dalam melakukan puja bakti dalam agama Buddha dibutuhkan sarana baik yang berupa fisik material maupun non fisik. Sarana fisik meliputi arsitektur sebagai wadah aktivitas; alat-alat upacara puja bakti berupa lilin, dupa, gong, dan lain-lain; serta atribut lainnya seperti jubah pemimpin kebaktian dan sebagainya. Sarana non fisik adalah parita-parita suci yang dibacakan pada saat puja bakti serta sikap batin dan jasmani dari individu yang melakukan aktivitas tersebut.

\section{A. Sarana Puja Bakti dalam Agama Buddha}

Ada berbagai tipe arsitektur sebagai sarana yang disunakan untuk wadah melakukan aktivitas puja bakti agama Buddha. Lima macam sarana puja bakti yang dimaksud, yaitu:

1. Arama

Arama dalah sebuah kompleks vihara yang besar, pada dasarnya, fungsi yang terdapat pada sebuah arama tidak banyak jauh berbeda dengan vihara. Perbedaannya secara jelas terlihat dari pengolahan tapaknya saja, dimana pada arama tersebut biasanya terdapat taman-taman yang luas.

2. Vihara

Sebuah vihara yang lengkap biasa terdiri atas Uposathagara (Gedung Uposatha), Dhammasala, Kuti dan Perpustakaan.

3. Cetiya

Cetiya merupakan tempat puja bakti bagi umat Buddha yang memiliki sarana yang lebih sederhana dibandingkan dengan vihara atau arama. Pada umumnya, di dalam sebuah cetiya hanya terdapat dharmasala berukuran kecil dan altar.

4. Candi

Fungsi candi sebagai sarana puja bakti, hampir mirip dengan stupa, dimana candi merupakan ekspresi yang lebih kompleks dari stupa. Candi merupakan perwujudan dari sebuah mandala atau cakra yang menggambarkan dunia yang berputar dalam lingkaran samsara. Hanya saja, biasanya candi berupa kompleks, bukan bersifat monolitik seperti stupa.

5. Stupa 


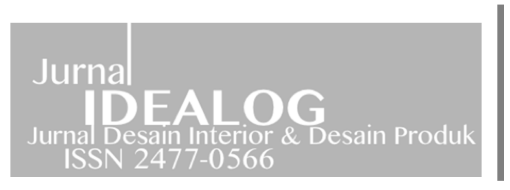

Jurnal I DEA LOG

Jurnal Desain Interior \& Desain Produk

Vol.1 No.1, April 2016

ISSN 2477 - 0566

Stupa adalah suatu arsitektur monumental yang dibangun dengan tujuan untuk penempatan sisa kremasi dari seorang suci atau Buddha, maupun seorang raja sejagat.

\section{B. Perkembangan Historis sebuah Cetiya}

Pada awalnya, pada masa Sang Buddha, cetiya adalah setiap tempat suci, altar, atau objek penghormatan. Pada zaman sebelum adanya keberadaan Patung Buddha, umat Buddha masih berdoa dan memuja di dalam cetiya atau kepada cetiya. Namun seiring perkembangan agama Buddha, khususnya di Indonesia, cetiya diartikan sebagai tempat atau ruangan puja bakti yang kecil. Cetiya ini pun biasanya terdapat di rumah-rumah umat Buddha sebagai tempat puja bakti keluarga.

\section{Jenis-jenis Cetiya}

Dalam Tradisi Agama Buddha, ada empat jenis cetiya, yaitu dhātucetiya, paribhogacetiya, dhammacetiya, dan uddesikacetiya. Tetapi, pembagian ini adalah hasil pengelompokan pada masa-masa setelah Buddhaparinibbāna.

\section{Dhätucetiya}

Dhātucetiya dikenal juga dengan nama Buddhasārīikacetiya, Sārīrikacetiya, atau relik Sang Buddha dalam bahasa sehari-hari. Relik ini adalah bagian organ jasmani Buddha yang telah diperabukan, dan dianggap sebagai benda yang sangat suci serta sangat berharga, karena merupakan bagian dari tubuh Buddha yang dianggap suci.

\section{Paribhogacetiya}

Paribhogacetiya adalah objek pujaan berupa benda atau peralatan yang pernah dipakai oleh Sang Buddha. Paribhogacetiya kurang banyak dibicarakan karena terbatas jumlahnya dan tidak ada penjelasan yang jelas terhadap penyimpanan alat-alat itu.

\section{Dhammacetiya}

Seiringnya waktu berjalan, pemujaan terhadap dua jenis cetiya sebelumnya semakin sulit dilakukan. Beberapa tempat pemujaan harus ditempuh dengan jarak jauh, bahkan hingga di luar negeri dan juga ada beberapa situs yang hilang dimakan zaman. Upaya atau solusi atas masalah ini adalah dengan diciptakanlah Dhammacetiya, dengan membangun stupa yang menyemayamkan sabda Buddha.

\section{Uddesikacetiya}

Dalam kehidupan Buddha, ada banyak tempat yang erat kaitannya dengan kehidupan Buddha. Diantaranya yang utama adalah Taman Lumbinī (tempat kelahiran Pangeran), Bodhgayā (tempat Pencapaian Bodhi), Sarnath/Bārāṇasī (tempat pertama kali membabarkan Dhamma), dan Kusinārā (tempat Buddha mencapai parinibbāna). Tempat-tempat itu dikelompokan sebagai jenis cetiya tersendiri dengan sebutan Uddesikacetiya.

Uddesikacetiya secara harfiah berarti benda-benda atau-tempat-tempat yang dikukuhkan sebagai objek pujaan. Uddesikacetiya bukan hanya berkaitan 
dengan benda, melainkan juga dengan waktu. Misalnya ketika Bodhisatta Gotama lahir untuk terakhir kalinya di lingkaran kehidupan, ketika Petapa Gotama mencapai penerangan sempurna, dan ketika Buddha Gotama mencapai parinibbāna. Ketiga kejadian ini dikenal dengan peringatan Visākhapūja, demikian pula dengan kejadian-kejadian lainnya yang dikukuhkan sebagai peringatan besar.

Dalam penjelasan tentang cetiya di atas, buddharūpa atau patung Buddha tidak dimasukan sebagai salah satu jenis cetiya. Demikian memang adanya, patung Buddha juga sering disebut Buddhapațimā atau bentuk tiruan diri Sang Buddha yang baru muncul ratusan tahun setelah sepeninggalan Beliau. Yaitu sekitar setelah India Kuno mendapat pengaruh budaya Yunani. Melewati sejarah yang amat panjang, pada akhirnya patung Buddha diterima dalam jenis uddesikacetiya.

Bila ditinjau secara geografis, awal pembuatan patung Buddha terjadi di wilayah India bagian utara dan barat laut, yaitu Kashmir, Pakistan, Afganistan sekarang, yang penduduk penganut agama Buddha-nya mengikuti tradisi Uttaranikāya, cikal bakal tradisi Ācariyavāda (atau Mahāyāna) sehingga dapat dikatakan objek puja dalam bentuk patung mulai dikenal dalam tradisi $\bar{A}$ cariyavāda, yang di sisi lain tradisi Theravāda pada zaman itu menganggap pembuatan patung Buddha adalah sikap kurang hormat terhadap Sang Buddha. Masyarakat tradisi Theravāda pada saat itu telah menerapkan beberapa aspek seni ke dalam penggambaran bentuk/keberadaan Sang Buddha. Namun, penggambaran tersebut tidak dengan cara menampilkan sosok Buddha dalam bentuk gambar atau patung secara jelas.

\subsection{Representasi dan Orientasi Ruang}

\section{A. Representasi dalam Desain Ruang Spiritual}

Menurut Barker (2006:9), representasi adalah aktivitas untuk menampilkan hubungan sosial perwujudan benda budaya yang digunakan oleh manusia sehingga dapat dipahami maknanya melalui teks-teks budaya, seperti nada (suara), bentuk visual (gambar), bangunan arsitektural, dan sebagainya. Representasi dan makna budaya memiliki materialitas, yang melekat pada bunyi, prasasti, objek, citra, buku, majalah, dan program televisi. Semua diproduksi, ditampilkan, digunakan, dan dipahami dalam konteks sosial tertentu. Di dalam representasi menurut Barker (2006:215), senantiasa terdapat masalah kekuasaan yang mengandung unsur pelibatan dan penyingkiran atau pengabaian.

Representasi menurut Piliang (2003:18), merupakan tindakan menghadirkan atau mempresentasikan sesuatu lewat sesuatu yang lain di luar dirinya, biasanya berupa tanda dan simbol. Dunia simbol merepresentasikan sesuatu di luar dirinya (realitas atau dunia). Hubungan antara simbol, tanda, dan dunia realitas bersifat referensial karena tanda merujuk pada realitas yang direpresentasikan. Keberadaan dunia tanda menurut Piliang (2004:46-47), hanya dimungkinkan bila ada dunia realitas yang direpresentasikannya.

Hollier (dalam Ikhwanuddin, 2005:86) menjelaskan bahwa desain bangunan atau arsitektur pada dasarnya merupakan general locus atau framework dari representasi. Desain arsitektural identik dengan ruang representasi. Desain arsitektural selalu merepresentasikan sesuatu yang lain di luar dirinya, yang membedakannya dengan desain bangunan lainnya. 
Desain bangunan dapat merepresentasikan sebuah agama, kekuatan politik, peristiwa, dan lain-lain.

Selanjutnya Klotz dalam Ikhwanuddin (2005:87) mengungkapkan bahwa desain bangunan atau arsitektur didefinisikan sebagai representasi dari sesuatu yang lain. Klotz juga menyatakan bahwa desain bangunan atau arsitektur posmodern menggunakan bentuk-bentuk metaforik dan simbolik untuk memperkaya pemaknaan. Metafora merupakan salah satu macam dari analogi bahasa dalam arsitektur yang dikemukakan oleh Charles Jenks. Menurut Jenks (dalam Widagdo, 1993:9), desain postmodern dapat dikaitkan dengan bahasa sehingga unsur metafor pada bangunan merupakan bagian dari representasinya. Desain posmodern menggunakan analogi bahasa sebagai bagian dari komunikasi desain, untuk menjelaskan maknanya. Charles Jenks adalah tokoh arsitek posmodern yang memelopori penerapan analogi antara bahasa dan desain.

Berkembangnya ilmu pengetahuan dan teknologi yang telah melahirkan teknologi komputer desain tiga dimensi (3D) dengan realitas virtual pada akhir abad ke-20 menyebabkan terjadinya perubahan media representasi desain. Representasi desain tidak lagi hanya bersifat materi atau fisik. Akan tetapi, juga bisa bersifat nonmateri dan nonfisik. Materialitas desain tersebut diambil alih oleh imaterialitas desain melalui teknologi komputer desain 3D dengan realitas virtual. Teknologi ini dapat membantu pembuatan citra simulasi,sebagai citra yang dikonstruksi melalui mekanisme teknologi komputer grafis. Hasil simulasinya adalah berupa ruang-ruang digital, virtual, dan menghasilkan citra gerak dengan durasi waktu artifisial. Citra gerak tersebut oleh Virilio disebut sebagai citra kronoskopi (Piliang, 2008:393). Realitas kronoskofis yang dibangun oleh elemen-elemen nonmaterial dan virtual telah mengubah secara mendasar karakter desain, yang tidak lagi sepenuhnya bersumber dari elemen-elemen ekstensif (material, fisikal dan spasial), tetapi juga berupa elemen-elemen intensif (nonmaterial, nonfisikal dan nonspasial).

Berdasarkan uraian di atas, dapat dirumuskan bahwa representasi adalah aktivitas untuk menampilkan hubungan sosial perwujudan benda budaya yang digunakan oleh manusia serta memiliki makna yang tervisualisasikan pada wujud benda budaya tersebut, seperti wujud desain arsitektural. Di dalam representasi terdapat unsur kekuasaan untuk menggunakan atau mengabaikan suatu wujud budaya yang tidak sesuai.

Sedangkan Chris Barker menyebutkan bahwa representasi merupakan kajian utama dalam cultural studies. Representasi sendiri dimaknai sebagai bagaimana dunia dikonstruksikan secara sosial dan disajikan kepada kita dan oleh kita di dalam pemaknaan tertentu. Cultural Study memfokuskan diri kepada bagaimana proses pemaknaan representasi itu sendiri.

Representasi berarti menggunakan bahasa untuk menyatakan sesuatu secara bermakna, atau mempresentasikan pada orang lain. Representasi dapat berwujud kata, gambar, sekuen, cerita, dsb yang 'mewakili' ide, emosi, fakta, dan sebagainya. Representasi bergantung pada tanda dan citra yang sudah ada dan dipahami secara kultural, dalam pembelajaran bahasa dan penandaan yang bermacam-macam atau sistem tekstual secara timbal balik. Hal ini melalui fungsi tanda 'mewakili' yang kita tahu dan mempelajari realitas (Hartley, 2010:265).

Representasi merupakan kegunaan dari tanda. Marcel Danesi mendefinisikannya sebagai berikut: "proses merekam ide, pengetahuan, atau pesan dalam Beberapa cara fisik disebut representasi. Ini dapat didefinisikan lebih tepat sebagai kegunaan dari tanda yaitu untuk menyambungkan, melukiskan, meniru sesuatu yang dirasa, dimengerti, diimajinasikan, atau dirasakan dalam Beberapa bentuk fisik dapat dikarakterisasikan sebagai proses 
konstruksi bentuk $X$ untuk menimbulkan perhatian kepada sesuatu yang secara material atau konseptual yaitu $\mathrm{Y}$, atau dalam bentuk spesifik $\mathrm{Y}, \mathrm{X}=\mathrm{Y}$ "

Pemikiran Danesi mengenai konsep representasi dicontohkan dengan sebuah konstruksi $\mathrm{X}$ yang dapat mewakilkan atau memberikan suatu bentuk kepada suatu materiil atau konsep tentang Y. Sebagai contoh misalnya konsep kecantikan seorang wanita diwakili atau ditandai melalui gambar seorang wanita yang memperlihatkan bagian tubuhnya dengan kulit yang putih menawan.

Konsep representasi digunakan untuk menggambarkan ekspresi hubungan antara teks iklan (media) dengan realitas. Representasi merupakan proses di mana para anggota sebuah budaya menggunakan bahasa untuk memproduksi makna. Bahasa dalam hal ini didefinisikan secara lebih luas, yaitu sebagai sistem apapun yang menggunakan tanda-tanda. Tanda disini dapat berbentuk verbal maupun nonverbal (Winarni, 2009:10).

Representasi sendiri merupakan proses sosial dan produk dari representing. Representasi menunjuk baik pada proses maupun produk dari pemaknaan suatu tanda representasi juga berarti proses perubahan konsep ideologi yang abstrak dalam bentuk konkrit. Representasi juga berarti konsep yang digunakan dalam proses sosial pemaknaan melalui sistem penandaan yang tersedia: dialog, tulisan, video, film, fotografi, dsb. Secara ringkas, representasi adalah produksi makna melalui bahasa. Menurut Stuart Hall representasi adalah salah satu praktik penting memproduksi budaya. Kebudayaan merupakan konsep yang sangat luas, kebudayaan menyangkut 'pengalaman berbagi'. Seseorang dikatakan berasal dari kebudayaan yang sama jika manusia-manusia yang ada disitu membagi pengalaman yang sama, membagi kode-kode kebudayaan yang sama, berbicara dalam bahasa yang sama dan saling berbagi konsep-konsep yang sama (Hall dalam Newsletter Kunci, 2000).

Dalam bab 3 buku Studying Culture: A Practical Introduction, terdapat tiga definisi dari kata 'to represent', yakni:

1. To stand in for. Hal ini dapat dicontohkan dalam kasus bendera suatu Negara, yang dikibarkan dalam suatu event olahraga, maka bendera tersebut menandakan keberadaan Negara yang bersangkutan dalam event tersebut.

2. To speak or act on behalf of. Contoh kasusnya adalah Paus menjadi orang yang berbicara dan bertindak atas nama umat Katolik.

3. To re-present. Dalam arti ini, misalnya tulisan sejarah atau biografi yang menghadirkan kembali kejadian-kejadian di masa lalu.

Dalam prakteknya, ketiga makna dari representasi ini dapat saling tumpang tindih. Oleh karena itu, untuk mendapat pemahaman lebih lanjut mengenai apa makna dari representasi dan bagaimana caranya beroperasi dalam masyarakat budaya, teori Hall akan sangat membantu. Menurut Hall sendiri dalam bukunya melalui representasi, suatu makna diproduksi dan dipertukarkan antar anggota masyarakat. Jadi dapat dikatakan bahwa, representasi secara singkat adalah salah satu cara untuk memproduksi makna.

Representasi bekerja melalui sistem representasi. Sistem representasi ini terdiri dari dua komponen penting, yakni konsep dalam pikiran dan bahasa. Kedua komponen ini saling berelasi. Konsep dari suatu hal yang kita miliki dalam pikiran kita, membuat kita mengetahui makna dari hal tersebut. Namun, makna tidak akan dapat dikomunikasikan tanpa bahasa. Sebagai contoh sederhana, kita mengenal konsep gelas dan mengetahui maknanya. Kita tidak akan dapat mengkomunikasikan makna dari gelas (misalnya, benda yang digunakan orang untuk minum) jika kita tidak dapat mengungkapkannya dalam bahasa yang dapat dimengerti oleh orang lain. 
Oleh karena itu, yang terpenting dalam sistem representasi ini adalah bahwa kelompok yang dapat berproduksi dan bertukar makna dengan baik adalah kelompok tertentu yang memiliki suatu latar belakang pengetahuan yang sama sehingga menciptakan suatu pemahaman yang (hampir) sama. Menurut Hall, berpikir dan merasa juga merupakan sistem representasi. Sebagai sistem representasi berarti berpikir dan merasa juga berfungsi untuk memaknai sesuatu. Oleh karena itu, untuk dapat melakukan hal tersebut, diperlukan latar belakang pemahaman yang sama terhadap konsep, gambar, dan ide (cultural codes).

Pemaknaan terhadap sesuatu dapat sangat berbeda dalam budaya atau kelompok masyarakat yang berlainan karena pada masing-masing budaya atau kelompok masyarakat tersebut ada cara-cara tersendiri dalam memaknai sesuatu. Kelompok masyarakat yang memiliki latar belakang pemahaman yang tidak sama terhadap kode-kode budaya tertentu tidak akan dapat memahami makna yang diproduksi oleh kelompok masyarakat lain.

Makna tidak lain adalah suatu konstruksi. Manusia mengkonstruksi makna dengan sangat tegas sehingga suatu makna terlihat seolah-olah alamiah dan tidak dapat diubah. Makna dikonstruksi melalui sistem representasi dan difiksasi melalui kode. Kode inilah yang membuat masyarakat yang berada dalam suatu kelompok budaya yang sama mengerti dan menggunakan nama yang sama, yang telah melewati proses konvensi secara sosial. Misalnya, ketika kita memikirkan 'rumah', maka kita menggunakan kata RUMAH untuk mengkomunikasikan apa yang ingin kita ungkapkan kepada orang lain. Hal ini karena kata RUMAH merupakan kode yang telah disepakati dalam masyarakat kita untuk memaknai suatu konsep mengenai 'rumah' yang ada di pikiran kita. (tempat berlindung atau berkumpul dengan keluarga). Kode, dengan demikian, membangun korelasi antara sistem konseptual yang ada dalam pikiran kita dengan sistem bahasa yang kita gunakan.

Teori representasi seperti ini memakai pendekatan konstruksionis, yang berargumen bahwa makna dikonstruksi melalui bahasa. Oleh karena itu, konsep (dalam pikiran) dan tanda (bahasa) menjadi bagian penting yang digunakan dalam proses konstruksi atau produksi makna. Maka dapat disimpulkan bahwa representasi adalah suatu proses untuk memproduksi makna dari konsep yang ada dipikiran kita melalui bahasa. Proses produksi makna tersebut dimungkinkan dengan hadirnya sistem representasi. Namun, proses pemaknaan tersebut tergantung pada latar belakang pengetahuan dan pemahaman suatu kelompok sosial terhadap suatu tanda. Suatu kelompok harus memiliki pengalaman yang sama untuk dapat memaknai sesuatu dengan cara yang nyaris sama.

\section{B. Orientasi sebagai Salah Satu Sifat Bentuk Ruang}

Salah satu unsur ruang yang perlu dipertimbangkan dalam perancangan sebuah wujud ruang adalah bentuk. Bentuk merupakan titik temu antara massa dan ruang. Bentuk juga dapat dihubungkan pada penampilan luar yang dapat dikenali seperti sebuah kursi atau seseorang yang mendudukinya. Menurut Vitruvius, tidak ada istilah bentuk. Bentuk bagi Vitruvius (dalam Saliya, 1999), bila mau dihubungkan dengan fungsi atau utilitas tentunya merupakan gabungan antara firmitas (teknik) dengan venustas (keindahan). Adapun pendapat lain yang mengatakan bahwa bentuk adalah obyek dalam persepsi kita memiliki wujud (Abecrombie, 1984:37). Dan wujud merupakan hasil konfigurasi tertentu dari permukaanpermukaan dan sisi bentuk (Ching, 1979:50).

Ciri-ciri pokok yang menunjukkan bentuk, dimana ciri-ciri tersebut pada kenyataannya dipengaruhi oleh keadaan adalah bagaimana cara kita memandangnya. Ching 
(1979) menyatakan bahwa bentuk dapat dikenali karena memiliki ciri-ciri visual tertentu, yaitu:

1. Wujud

Wujud adalah hasil konfigurasi tertentu dari permukaan-permukaan dan sisi-sisi bentuk.

\section{Dimensi}

Dimensi suatu bentuk adalah panjang, lebar, tinggi. Dimensi-dimensi ini menentukan proporsinya. Adapun skalanya ditentukan oleh perbandingan ukuran relatifnya terhadap bentuk-bentuk lain di sekelilingnya.

\section{Warna}

Warna menandakan corak, intensitas dan nada permukaan pada suatu bentuk. Warna adalah atribut yang paling mencolok yang membedakan suatu bentuk terhadap lingkunganya. Warna juga mempengaruhi bobot visual pada bentuk.

\section{Tekstur}

Adalah karakter permukaan suatu bentuk. Tekstur mempengaruhi perasaan kita pada waktu menyentuh, juga pada saat kualitas pemantulan cahaya menimpa permukaan benda tersebut.

5. Posisi

Adalah letak relatif suatu bentuk terhadap suatu lingkungan atau medan visual.

6. Orientasi

Adalah posisi relatif suatu bentuk terhadap bidang dasar, arah mata angin atau terhadap pandangan seseorang yang melihatnya.

7. Inersia Visual

Adalah derajat konsentrasi dan stabilitas suatu bentuk. Inersia suatu bentuk tergantung pada geometri dan orientasi relatifnya terhadap bidang dasar dan garis pandangan kita.

\section{Metoda Penelitian}

Penelitian ini bertujuan untuk memperoleh data kualitatif sebagai salah satu faktor yang mempengaruhi dalam proses berarsitektur dengan menggunakan pendekatan fenomenologi. Dalam memperoleh data kualitatif tersebut dilakukan dengan cara melihat fenomena berbagai pendekatan yakni melihatnya melalui objek riil berupa produk arsitektur itu sendiri, dan aktivitas yang terjadi pada produk arsitektur tersebut. Dengan demikian, fenomena dapat diobservasi melalui cara-cara pengamatan dan penghayatan langsung.

Bangunan bernafaskan religius merupakan suatu produk desain yang pada umumnya mengandung suatu fenomena tertentu, oleh sebab itu dalam mengungkap data kualitatif dari objek studi berupa bangunan religi diperlukan pendekatan lebih dulu mengkaji fisik material, baru kemudian fisik spasial. Demikian pula halnya dengan bangunan religi penganut agama Buddha yang mengandung suatu fenomena tertentu. Di balik wujud fisik arsitekturnya sebagai tempat yang menampung kegiatan religius, objek studi ini muncul pada saat agama Buddha berkembang di India sekitar 588 SM dan terus berkembang hingga saat ini di 
Indonesia dengan wujud fisiknya yang masih nyata, dapat diobservasi, terkait isu bahwa adanya pergeseran makna atau tidak.

Cetiya sebagai salah satu sarana puja bakti dalam agama Buddha memiliki peranan cukup penting. Dalam melakukan aktivitas puja bakti, ruang sebagai wadah dari pergerakan aktivitas merupakan suatu kebutuhan. Sebaliknya aktivitas puja bakti pun memerlukan sarana arsitektur sebagai objek puja bakti, selain sekedar wadah aktivitas. Dengan kata lain, produk desain pun menjadi suatu kebutuhan dalam menjalankan praktek spiritual dalam kehidupan beragama seiring dengan semakin maraknya perkembangan sisi spiritual sebagai kebutuhan hidup manusia.

Sifat dari pendekatan yang digunakan adalah sinkronik-diakronik dengan pertimbangan bahwa kajian mengandung nilai historis tinggi dan terus berkembang sampai dengan saat ini. Sinkronik bertujuan menemukan variasi atau ragam fenomena dan fakta yang ada hingga saat ini, namun berhubungan erat dengan usia objek studi dan perkembangannya dari mulai muncul hingga saat ini yang mengalami berbagai perubahan serta memiliki nilai historis dan makna spiritual. Lain halnya dengan diakronik yang hanya mengobsevasi objek studi pada saat ini saja sebagai elemen fisik spasial yang menjadi alat untuk menemukan ragam fenomena dan fakta tersebut. Metode pengumpulan data pada penelitian ini dilakukan dengan studi literatur, studi lapangan, dan wawancara.

Pembahasan yang dilakukan dengan mendeskripsikan tipe-tipe cetiya yang berada di ranah publik dan ranah privat. Objek penelitian tersebut diambil berdasarkan pergeseran fisik yang terlihat secara bentuk dan fungsi dari cetiya awal yang berupa bangunan monumental. Adapun cetiya yang diambil sebagai studi kasus yakni cetiya pada bangunan publik dan cetiya pada bangunan hunian. Pembahasan kedua cetiya tersebut akan diawali dengan penjelasan umum terlebih dahulu sebelum dilanjutkan dengan pembahasan cetiya yang diklasifikasikan berdasarkan nilai ruang, tatanan ruang dan elemen ruang.

\section{Hasil/Temuan}

\subsection{Cetiya pada Bangunan Publik}

a. Deskripsi Umum

Cetiya ini terdapat pada sebuah perusahaan sepatu bernama General Shoe Factory, dan terletak di Jalan Cigondewah No. 1, Bandung. Kawasan ini pada umumnya dipadati oleh perusahaan-perusahaan yang bergerak di bidang industri dan manufaktur.

Pada tahun 1992, pemilik menjadikan sebuah ruang di perusahaannya untuk difungsikan sebagai cetiya dalam upaya pemenuhan kebutuhan pribadi religiusnya sehingga kebanyakan aktivitas-aktivitas religius yang dilakukan bersifat personal. Namun di saat-saat tertentu ada juga aktivitas bersama yang dilakukan dengan pihak luar perusahaan pada ruang cetiya tersebut. 

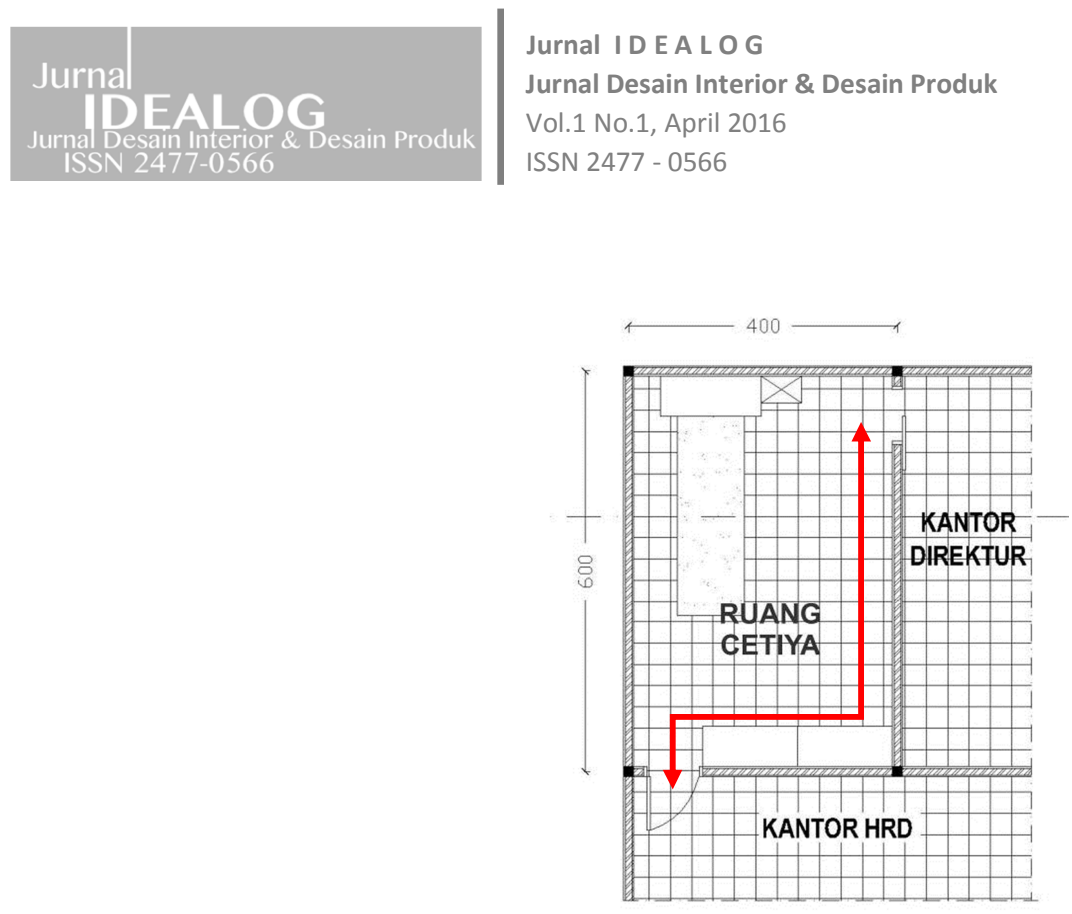

Gambar 4. Denah layout Cetiya Pabrik General Shoe Sumber: Dokumentasi Pribadi, 2015

Cetiya pada perusahaan ini berupa suatu ruang peribadatan yang terletak di ruang peralihan antara ruang Direktur Utama dan ruang kantor Manager Personalia. Lokasi cetiya tersebut berada di ruang peralihan, sehingga akses keluar masuk ruang ini kerap dilalui oleh siapapun yang berkepentingan dan akan menuju ruang Direktur Utama.

Keberadaan tata ruang Cetiya ini disusun secara sederhana dengan meletakan meja altar terbuat dari kayu berukuran $150 \mathrm{~cm} \times 60 \mathrm{~cm} \times 135 \mathrm{~cm}$ dengan finishing material melamic warna coklat tua. Di atas meja altar diletakkan beberapa atribut keagamaan seperti beberapa patung kecil, cermin, gambar Sang Buddha, cangkir kecil serta lilin listrik dalam keadaan menyala. Pada lemari tersebut beberapa rak penyimpanan berupa laci dan meja tambahan yang dapat ditarik serta rak penyimpanan di bagian bawah dengan ukuran cukup besar untuk menyimpan patung Sang Buddha dan beberapa atributnya. Di sebelah kanan meja altar terdapat lemari kecil berwarna coklat muda, dilengkapi dengan tiga buah rak penyimpanan yang dipergunakan untuk alat keperluan kegiatan peribadatan.

Lantai ruangan tempat Cetiya berada menggunakan lantai keramik berukuran $30 \mathrm{~cm}$ x $30 \mathrm{~cm}$ berwarna putih dan tepat di depan meja altar diletakkan karpet berwarna merah yang digunakan ketika kegiatan peribadatan berlangsung.
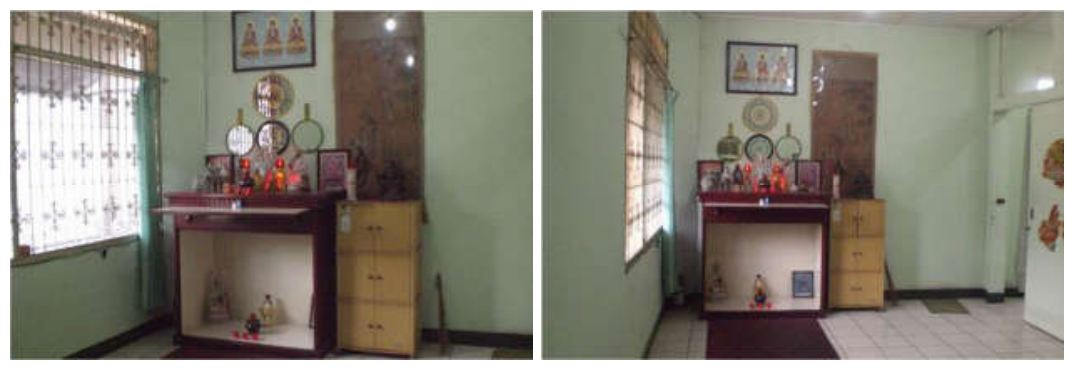

Gambar 5. Ruang Cetiya di Pabrik General Shoe Factory

Sumber: Dokumentasi Pribadi, 2015 
Pencahayaan pada ruang tersebut menggunakan pencahayaan alami dan pencahayaan buatan. Hal tersebut dikarenakan letak altar yang berada persis di samping bukaan berupa jendela, sehingga cahaya dapat masuk ke dalam ruang pada waktu siang hari. Sedangkan pencahayaan buatan pada ruang tersebut.

\section{b. Nilai Ruang Cetiya Pada Bangunan Publik}

Pada ruang ibadah Cetiya terdapat beberapa aspek nilai ruang, yakni pusat, jalur (path), dan ranah (domain). Masing-masing nlai ruang tersebut akan dibahas pada masing-masing studi kasus cetiya sebagai berikut:

1. Pusat (center)

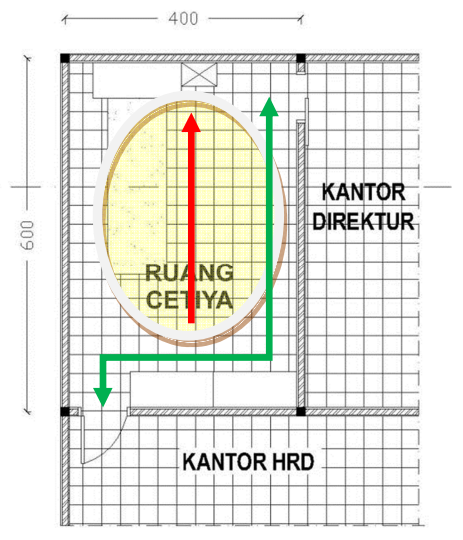

Gambar 6. Analisis Jalur Memusat Cetiya Pada Bangunan Publik Sumber: Rekonstruksi Penulis, 2015

Penempatan furnitur altar pada sisi sudut kanan ruang, tidak membentuk susunan memusat yang dominan, namun masih mencerminkan adanya suatu penekanan terhadap obyek, yakni obyek penghormatan terhadap patung Buddha. Pada ruangan tersebut terdapat karpet merah yang digunakan sebagai elemen lantai pada ruang untuk memberi kejelasan pusat. Adapun elemen pelengkap lainnya seperti lukisan, lilin dan lain-lain, memiliki komposisi sejajar baik dengan sumbu elemen furnitur maupun lantai, sehingga dapat memperkuat kesan memusat yang stabil. 

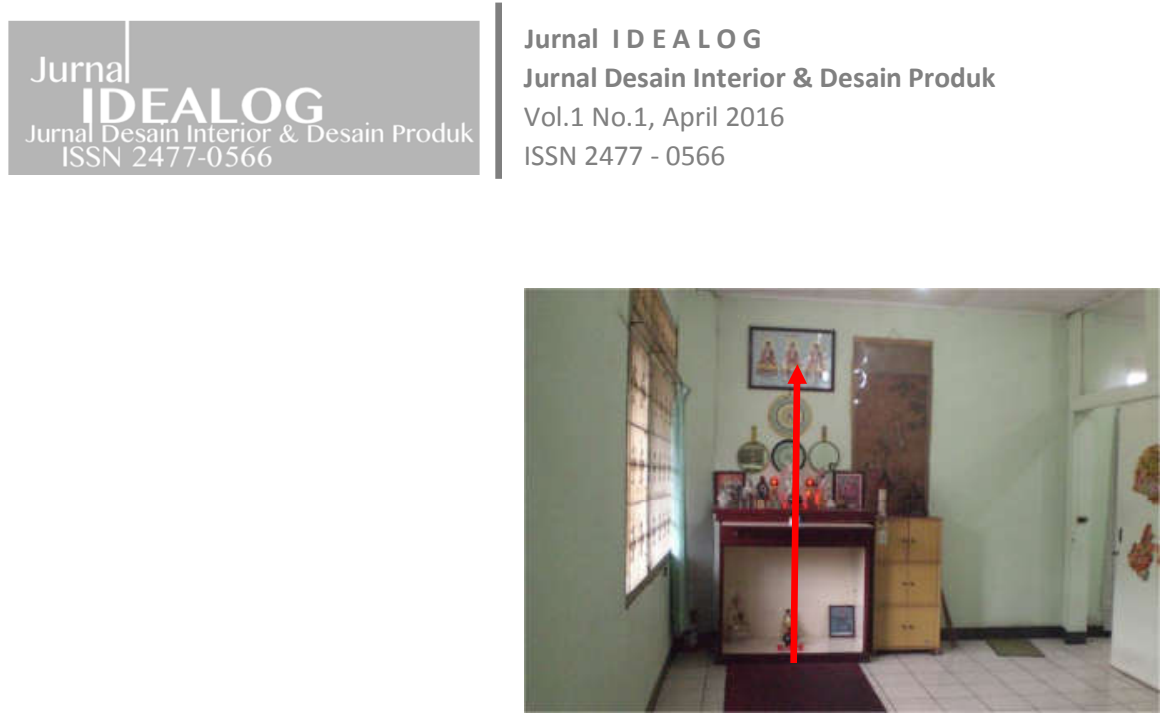

Gambar 7. Ruang Cetiya Bangunan Publik Sumber: Rekonstruksi Penulis, 2015

2. Jalur (path)

Pada ruang cetiya ini, ada 6 (enam) buah pergerakan yang terbentuk, yaitu:

1. Pergerakan masuk ruang kantor direktur

2. Pergerakan keluar ruang kantor direktur

3. Pergerakan masuk ruang cetiya

4. Pergerakan keluar ruang cetiya

5. Pergerakan masuk meja print umum

6. Pergerakan keluar meja print umum

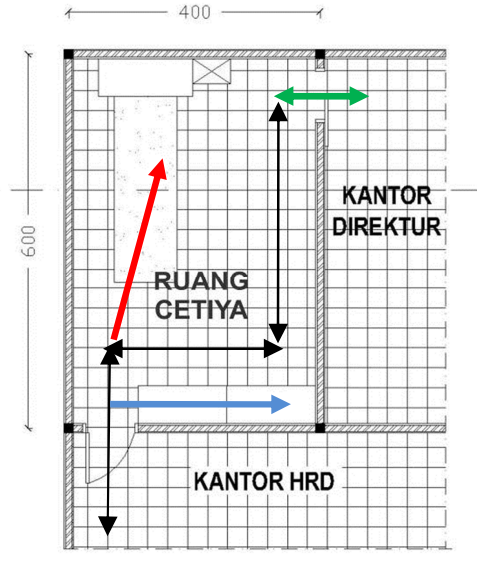

$$
\begin{aligned}
& \text { KETERANGAN: } \\
& \text { Sirkulasi Cetiya } \\
& \text { Sirkulasi Kantor Direktur } \\
& \text { Sirkulasi Meja Print Umum } \longleftrightarrow
\end{aligned}
$$

Gambar 8. Jalur Pergerakan Cetiya Pada Bangunan Publik Sumber: Rekonstruksi Penulis, 2015 
Pada Gambar 8. tampak bahwa ruangan tersebut memiliki sirkulasi keluar masuk ruang cetiya yang jelas, karena elemen penanda dapat langsung terlihat dari akses pintu masuk. Sedangkan, sirkulasi menuju ruang direktur dan meja print agak rancu karena setiap orang yang masuk ke dalam ruangan tersebut harus melalui ruang peralihan yang berfungsi sebagai ruang cetiya. Dengan demikian, elemen penanda pada ruangan tersebut tidak jelas sehingga sulit diidentifikasikan.

\section{Ranah (domain)}

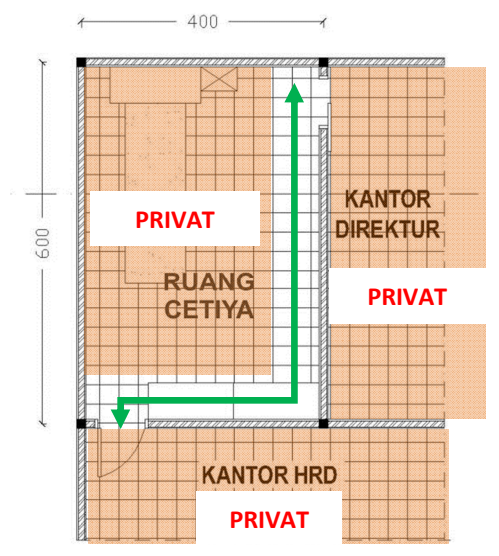

Gambar 9. Ranah Publik dan Privat Cetiya Pada Bangunan Publik Sumber: Rekonstruksi Penulis, 2015

Ruang Cetiya ini berada di area privat, yakni ruang peralihan dari kantor manager personalia menuju kantor direktur. Penempatan furnitur dan karpet pada ruang Cetiya tersebut membentuk domain tersendiri sehingga dapat dikategorikan ke dalam ranah privat. Dengan demikian, zoning ruang Cetiya tersebut dapat dikategorikan ke dalam ranah privat.

\section{c. Tatanan Ruang Cetiya Pada Bangunan Publik}

\section{Fungsi}

Ruang ini mewadahi aktivitas ibadah bagi pemilik pabrik sebagai ruang ibadah pada fungsi bangunan publik, tak lantas mengakibatkan ruang cetiya ini menjadi ruang ibadah publik pula. Dengan susunan furnitur dan atribut yang ada, nilai simbolis masih dapat dirasakan, namun jika ditinjau dari lokasi ruang yang dilintasi oleh jalur sirkulasi dari dan menuju ruang direktur, maka nilai-nilai dan orientasi kesakralan mengalami sedikit penurunan bila dibandingkan dengan ruang yang dilingkupi elemen ruang tertutup.

\section{Pola}

Pola yang terjadi cenderung menyerupai pola grid dimana ruang-ruang yang terbentuk adalah akibat sumbu-sumbu aksial vertikal dan horisontal, yang membentuk area aktivitas yang berbeda-beda nilai ruangnya. 

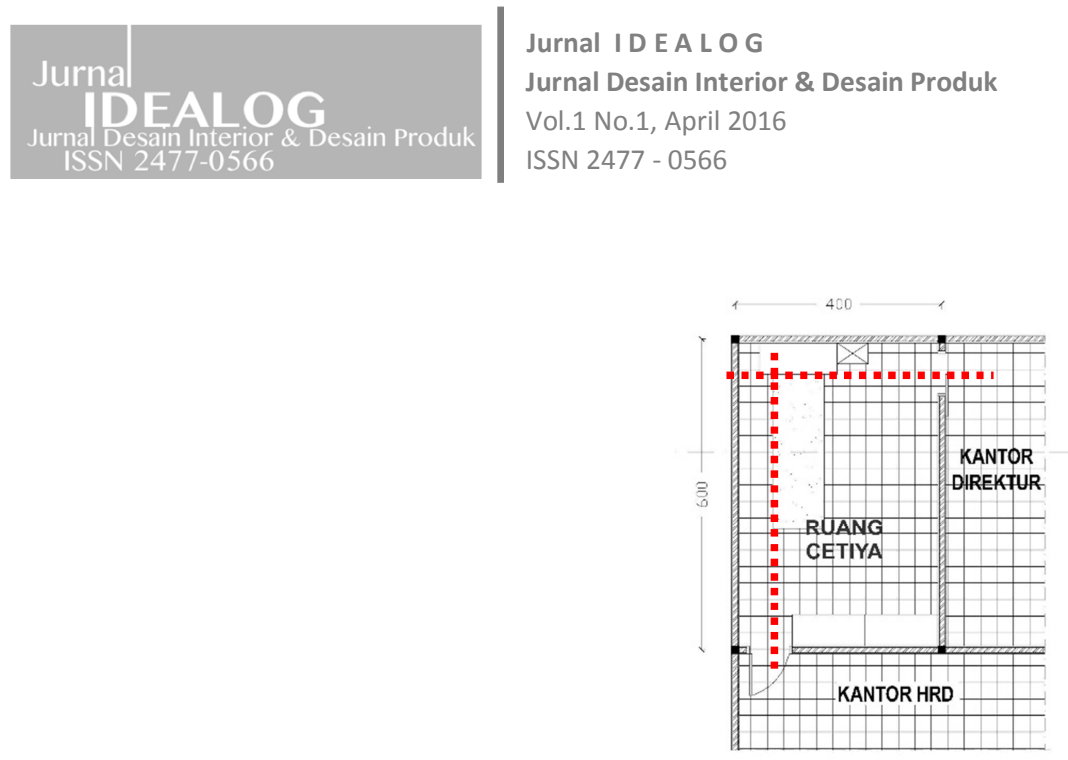

Gambar 10. Denah Cetiya pada Bangunan Publik

Sumber: Rekonstruksi Penulis, 2015

\section{Hierarki}

Pada ruang cetiya ini tidak nampak tingkatan hierarki, namun penurunan yang hanya melintasi ruang saja seolah-olah ruang sirkulasi. Kadar privatisasi ruang terjadi ketika ada pergerakan aktivitas pengguna ruang digunakan ketika menjelang sore hari yakni berupa sebuah buah Lampu TL 40 watt.

\subsection{Cetiya pada Bangunan Hunian}

\section{a. Deskripsi Umum}

Jenis Cetiya ini berada pada bangunan hunian yang terletak di Jalan Sukahaji Permai No. 16A, Bandung. Cetiya tersebut digunakan oleh sebuah keluarga beranggotakan enam orang, yakni ayah, ibu, dan empat orang anak. Bangunan cetiya ini dibuat secara khusus untuk kegiatan peribadatan bagi seluruh anggota keluarga yang diadakan secara rutin pada pagi hari sebelum mereka beraktivitas dan pada hari-hari besar keagamaan.

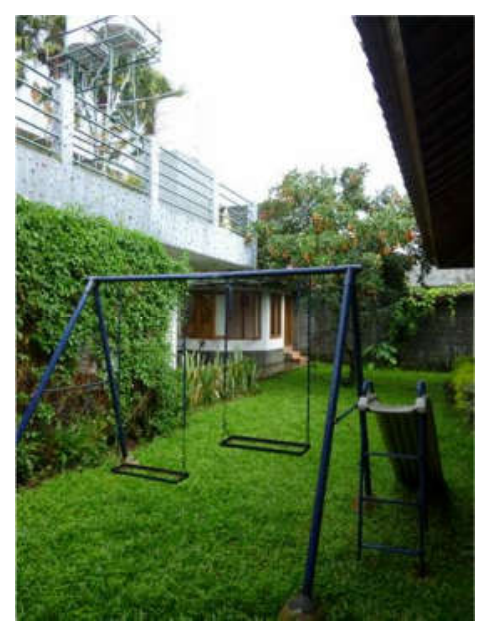

Gambar 11. Bangunan Cetiya di Bagian Belakang Tapak Bangunan Utama Sumber: Dokumentasi Pribadi, 2015 


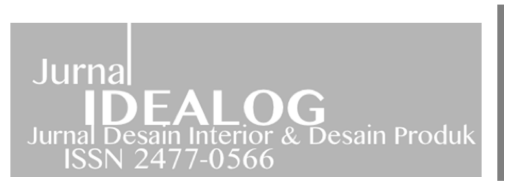

Jurnal I DEA LOG

Jurnal Desain Interior \& Desain Produk

Vol.1 No.1, April 2016

ISSN 2477 - 0566

Cetiya pada bangunan hunian yang dibangun secara khusus ini merupakan cetiya yang jarang ditemukan. Pada umumnya, pemilik cetiya tipe ini adalah keluarga dengan status sosial menengah ke atas, dan biasanya memiliki ruang khusus atau bangunan khusus yang dibangun baik menyatu maupun terpisah dengan bangunan hunian sebagai bangunan utamanya.

Cetiya memiliki ukuran $400 \mathrm{~cm} \times 400 \mathrm{~cm} \times 250 \mathrm{~cm}$ dengan bentuk bangunan trapesium berupa bentuk setengah dari bentuk segi delapan yang terletak di bagian belakang halaman rumah sehingga memiliki sirkulasi udara cukup baik. Akses menuju cetiya tersebut juga dapat dijangkau dengan baik sehingga dapat mendukung terlaksananya kegiatan peribadatan dengan baik.

Di dalam bangunan Cetiya tersebut terdapat sebuah meja altar cukup besar untuk meletakkan sebuah patung Sang Buddha dengan tinggi $135 \mathrm{~cm}$ dan beberapa atribut yang seringkali digunakan dalam kegiatan peribadatan, yakni cangkir, air, tempat dupa, dupa, lilin dan beberapa atribut keagamaan lainnya agar dapat mendukung jalannya kegiatan peribatan dengan baik. Lantai Cetiya tersebut menggunakan keramik dengan ukuran $30 \mathrm{~cm} \times 30 \mathrm{~cm}$ berwarna coklat muda agak kemerahan dan agak bertekstur dan disertai pula dengan keramik berpola segi delapan yang berada di tengah ruangan mengikuti bentuk bangunan Cetiya tersebut.

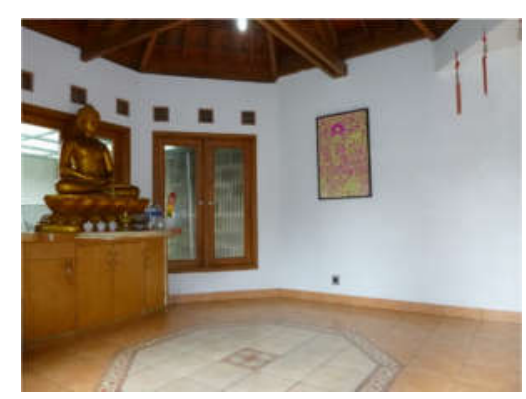

Gambar 12. Dinding ruangan Cetiya dengan gambar Sang Buddha Sumber: Dokumentasi Pribadi, 2015

Pada dinding Cetiya tersebut terdapat beberapa lubang udara dan jendela dengan bukaan cukup lebar sehingga memudahkan keluar masuknya udara dan cahaya dengan cukup baik. Adapun gambar Sang Buddha yang diletakkan pada dinding ruang yang berfungsi sebagai elemen pelengkap.

\section{b. Nilai Ruang Pada Cetiya Bangunan Hunian}

\section{a. Pusat (center)}

Penempatan furnitur altar pada sisi sudut tengah ruang, berhimpitan dengan salah satu dinding ruang. Penempatan furniture tersebut membentuk susunan memusat yang dominan dan mencerminkan adanya suatu penekanan terhadap obyek, yakni obyek penghormatan terhadap patung Buddha. Pola lantai pada ruang cetiya tersebut menggunakan beberapa warna yang berbeda dan membentuk pola memusat 
yang digunakan untuk memberi kejelasan pusat. Adapun elemen pelengkap lainnya seperti lilin, tiga buah cangkir, hiolo dan lain-lain, yang berada di hadapan patung Buddha memiliki komposisi sejajar baik dengan sumbu elemen furnitur maupun dengan lantai, sehingga dapat memperkuat kesan memusat yang stabil.
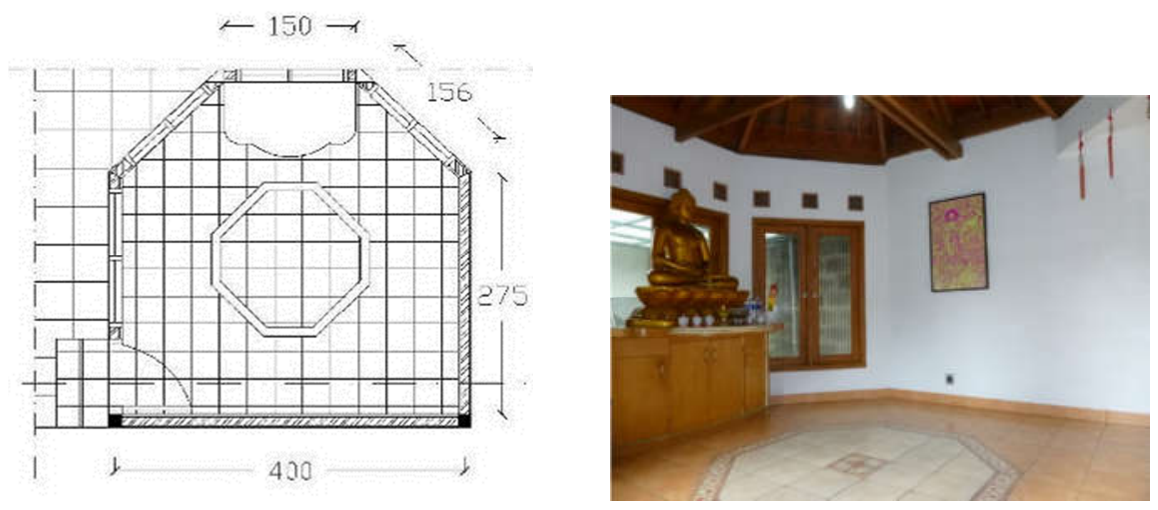

Gambar 13. Ruang Cetiya pada bangunan Hunian

b. Jalur (path)

Sumber: Dokumentasi Penlulis, 2015

Pada ruang cetiya pada bangunan hunian ini hanya terdapat dua buah pergerakan yang terbentuk, yakni:

1. Pergerakan masuk ruang cetiya

2. Pergerakan keluar ruang cetiya

Pergerakan ruang cetiya pada bangunan hunian ini memiliki pergerakan dengan jumlah yang jauh lebih sedikit daripada pergerakan cetiya pada bangunan publik. Hal tersebut dikarenakan ruang cetiya pada bangunan hunian ini dirancang secara khusus sebagai tempat ibadah keluarga yang bersifat privat tanpa melibatkan aktivitas lainnya di samping kegiatan peribadatan.

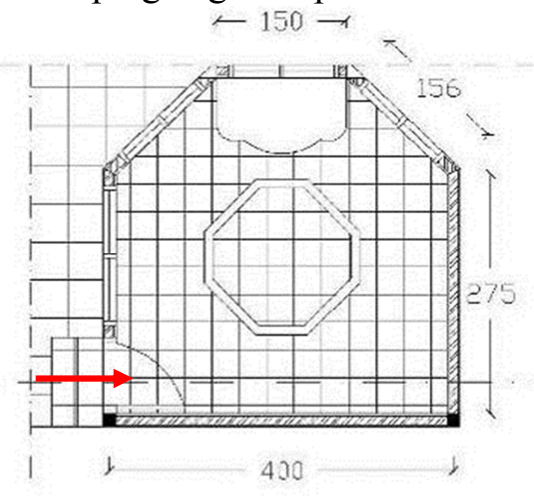

KETERANGAN :

Sirkulasi Cetiya $=$

Gambar 14. Jalur Pergerakan Cetiya Pada Bangunan Hunian Sumber: Rekonstruksi Penulis, 2015 
Pada Gambar 14. tampak bahwa pada ruang cetiya pada bangunan hunian tersebut memiliki sirkulasi keluar masuk ruang cetiya yang sangat jelas, karena elemen penanda dapat langsung terlihat dari akses pintu masuk dan keluarnya. Dengan demikian, elemen penanda pada ruangan tersebut dapat dikatakan sangat jelas sehingga mudah untuk diidentifikasikan oleh user, karena hanya terdapat sebuah akses yang dapat digunakan sebagai akses masuk sekaligus akses keluar dari ruang cetiya tersebut.

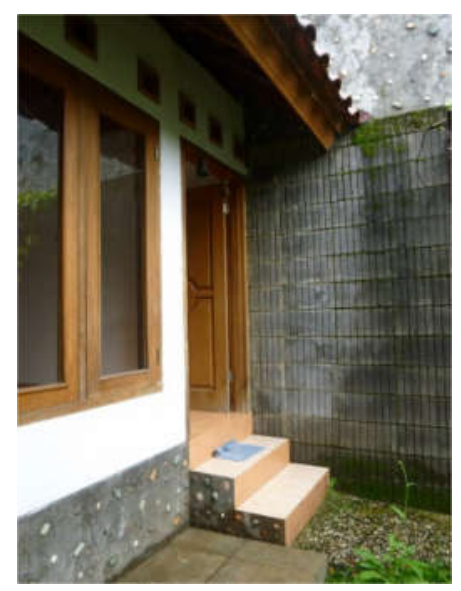

Gambar 15. Akses masuk dan akses keluar pada ruang Cetiya dalam bangunan hunian. Sumber: Dokumentasi Pribadi, 2015

\section{c. Ranah (domain)}

Ruang Cetiya ini berada di area privat, yakni terletak di bagian dalam rumah tinggal yang berdampingan dan berhadapan dengan taman atau halaman belakang rumah tersebut.

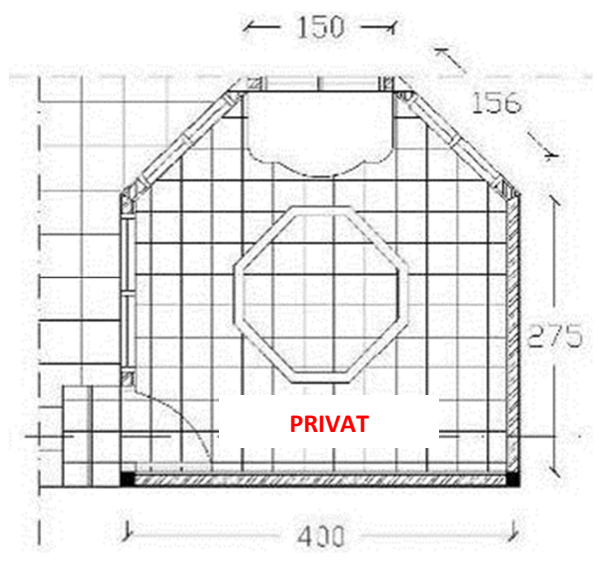

Gambar 16. Ranah publik dan ranah privat pada ruang Cetiya dalam bangunan hunian. Sumber: Rekonstruksi Penulis, 2015

Penempatan bangunan ruang cetiya yang dibangun secara khusus sebagai tempat ibadah keluarga membentuk domain tersendiri sehingga dapat dikategorikan ke 


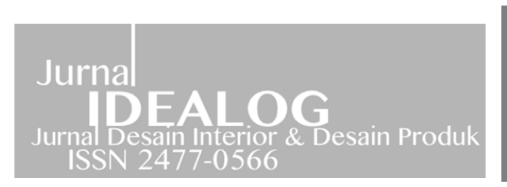

dalam ranah privat. Dengan demikian, zoning ruang Cetiya dalam bangunan hunian ini dapat dikategorikan ke dalam ranah privat.

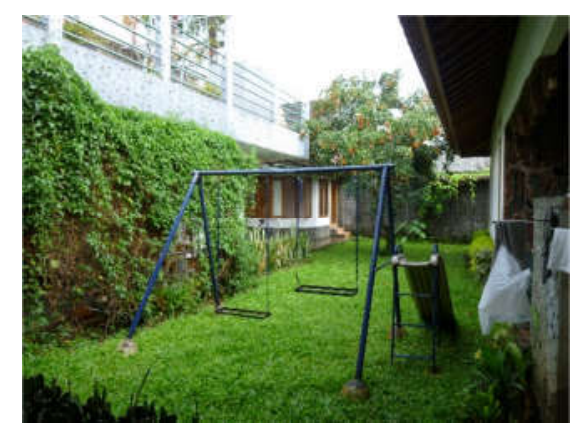

Gambar 17. Penempatan bangunan khusus ruang Cetiya dalam bangunan hunian Sumber: Dokumentasi Pribadi, 2015

d. Tatanan Ruang Pada Cetiya Bangunan Hunian

1. Fungsi

Ruang ini mewadahi aktivitas bagi seluruh penghuni rumah, yakni baik berfungsi sebagai ruang meditasi pribadi, maupun ruang ibadah rutin (bila para penghuni tidak bisa melakukan ibadah di vihara). Di samping itu pula, cetiya tersebut terkadang dapat berfungsi sebagai ruang kegiatan kumpul komunitas bila memang diperlukan. Ruang cetiya ini digunakan sesuai dengan fungsi awalnya, yakni ruang ibadah, sehingga keutuhan nilai simbolisnya tetap terjaga baik serta kesatuan nilai-nilai ruang yang masih dijaga, seperti melepas alas kaki sebelum masuk ke ruang cetiya. Dengan demikian, orientasi sakralitas pada ruang cetiya ini menjadi jelas.

2. Pola

Pola yang terbentuk pada ruang cetiya ini memusat, baik bentuk ruang, pola furnitur maupun pola lantai, semua elemen membentuk pola ruang yang memusat.

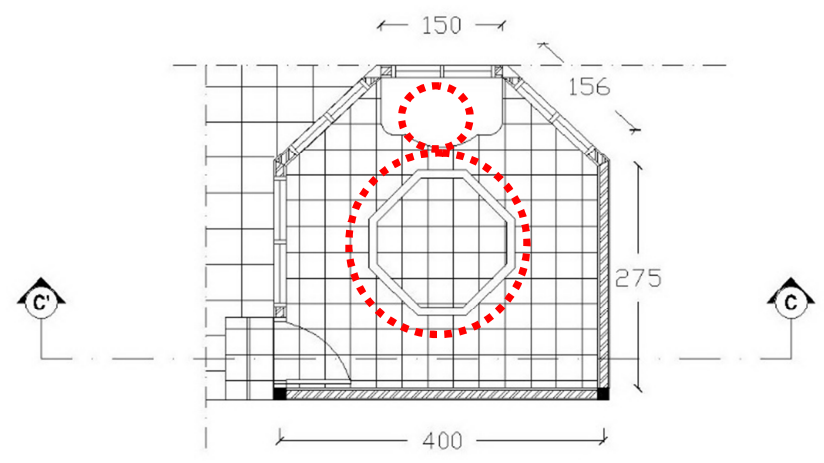

Gambar 18. Denah Cetiya pada Bangunan Hunian Sumber: Rekonstruksi Penulis, 2015 
3. Hierarki

Lokasi ruang cetiya pada bangunan ini di bagian belakang kompleks rumah yang terpisah oleh kebun, menjadikan hierarki ruang ini menjadi sakral dan tinggi.
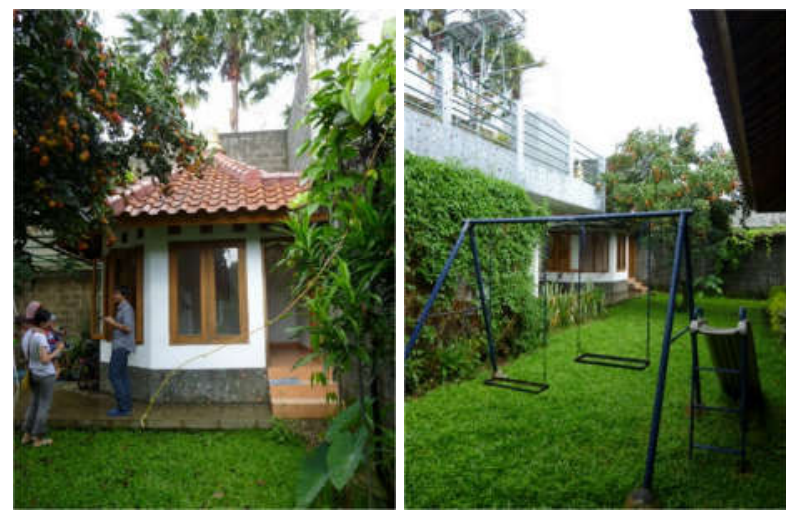

Gambar 19. Lokasi Cetiya pada Bangunan Hunian Sumber: Dokumentasi Penulis, 2015

Berdasarkan pemaparan deskripsi objek, nilai ruang dan tata ruang pada kedua buah jenis ruang cetiya yakni ruang cetiya pada ruang publik dan privat, maka dapat disimpulkan sebagai berikut:

Tabel 1. Simpulan Nilai Ruang pada Studi Kasus Ruang Cetiya

\begin{tabular}{|c|c|c|c|c|}
\hline No & Jenis Cetiya & Pusat (Center) & $\begin{array}{c}\text { Jalur } \\
\text { (Path) }\end{array}$ & $\begin{array}{c}\text { Ranah } \\
\text { (Domain) }\end{array}$ \\
\hline 1. & $\begin{array}{c}\text { Cetiya pada } \\
\text { Bangunan } \\
\text { Publik }\end{array}$ & $\begin{array}{c}\text { Elemen lantai } \\
\text { (karpet merah) }\end{array}$ & $\begin{array}{c}\text { 6 buah } \\
\text { Pergerakan }\end{array}$ & Privat \\
\hline 2. & $\begin{array}{c}\text { Cetiya pada } \\
\text { Bangunan } \\
\text { Hunian }\end{array}$ & Pola lantai & $\begin{array}{c}2 \text { buah } \\
\text { Pergerakan }\end{array}$ & Privat \\
\hline
\end{tabular}

Berdasarkan pemaparan Tabel 1. maka dapat diketahui bahwa dari kedua jenis ruang Cetiya yang dijadikan sebagai objek studi kasus memiliki pusat (center), jalur (path) dan ranah (domain) yang bervariatif. Keberadaan halhal tersebut dapat memperkuat nilai sebuah ruang, khususnya ruang ibadah cetiya melalui penempatan suatu objek, sirkulasi ruang dan ranah yang jelas agar dapat berjalan sesuai dengan fungsinya.

Nilai ruang pada beberapa studi kasus ruang cetiya bila ditinjau berdasarkan polanya memiliki pengaruh terhadap banyaknya jalur (path) yang tercipta sehingga menghasilkan suatu pergerakan dalam jumlah tertentu. Namun banyak jumlahnya pergerakan tersebut tidak berpengaruh terhadap ranahnya (domain). Sedangkan berdasarkan pemaparan tatanan ruang pada studi kasus 
ruang cetiya pada bangunan publik dan bangunan privat, maka dapat disimpulkan sebagai berikut:

Tabel 2. Simpulan Tatanan Ruang pada Studi Kasus Ruang Cetiya

\begin{tabular}{|c|l|c|c|c|}
\hline No & Jenis Cetiya & Fungsi & Pola & Hierarki \\
\hline 1. & $\begin{array}{l}\text { Cetiya pada } \\
\text { Bangunan } \\
\text { Publik }\end{array}$ & $\begin{array}{c}\text { Mewadahi aktivitas } \\
\text { ibadah bagi pemilik } \\
\text { pabrik }\end{array}$ & Grid & $\begin{array}{c}\text { Tidak } \\
\text { ada }\end{array}$ \\
\hline 2. & $\begin{array}{l}\text { Cetiya pada } \\
\text { Bangunan } \\
\text { Hunian }\end{array}$ & $\begin{array}{c}\text { Mewadahi aktivitas } \\
\text { bagi seluruh } \\
\text { penghuni rumah. }\end{array}$ & Memusat & Ada \\
\hline
\end{tabular}

Berdasarkan pemaparan Tabel 2, maka dapat kita ketahui bahwa kedua buah ruang cetiya tersebut dapat mewadahi aktivitas kegiatan peribadatan baik bagi seluruh penghuni berupa ruang cetiya yang bersifat privat dalam ruang hunian, maupun bagi para umat berupa ruang cetiya yang bersifat publik dengan orientasi sakralitas yang jelas.

Pada Tabel 2. tampak bahwa pola ruang cetiya-cetiya tersebut pun beragam, yakni grid dan memusat. Cetiya pada bangunan hunian memiliki pola ruang grid, pola ini seringkali ditemukan pada bangunan-bangunan cetiya pada umumnya. Ching (1996:74-75) berpendapat bahwa pola dengan bentuk terpusat dapat mendominasi sebuah titik yang berada di dalam ruang, maupun menempati pusat suatu bidang tertentu yang seringkali digunakan menjadi simbol bagi tempat-tempat suci untuk mengenang kebesaran seorang tokoh atau peristiwa. Dengan demikian, ruang cetiya yang memiliki bentuk pola ruang dan sirkulasi terpusat tentunya akan lebih mudah untuk diidentifikasikan oleh para umatnya sebagai pengguna ruang daripada pola linier dan grid.

Berdasarkan pemaparan pada Tabel 2. maka dapat disimpulkan bahwa ruang cetiya pada bangunan hunian memiliki hierarki yang jelas. Ruang dengan pola memusat dapat menunjukkan hierarki dengan jelas, sedangkan ruang dengan pola yang tidak memusat yakni ruang cetiya pada bangunan publik (pada studi kasus ini adalah pola grid) tidak dapat menunjukkan hierarki ruangnya. Keberadaan hieraki yang jelas pada suatu ruang dapat menunjukkan bahwa cetiya tersebut berfungsi sebagai bangunan khusus tempat ibadah melalui kesan ruang yang diciptakannya, yakni sakral dan bernilai tinggi.

\section{Kesimpulan}

Bila kita telaah bahasan tatanan ruang pada kedua studi kasus cetiya berdasarkan korelasi antar aspek-aspek pembentuknya, maka dapat ditarik kesimpulan sebagai berikut:

1. Hubungan antara Fungsi Ruang dan Pola Ruang

Ruang cetiya dengan fungsi kelompok atau umum cenderung membentuk pola yang memusat, sehingga orientasi terhadap objek menjadi jelas. Berbeda halnya dengan 
cetiya yang memiliki fungsi personal (privat), walaupun sirkulasi dan pola ruang tidak dominan memusat, namun orientasi tetap tampak jelas sehingga nilai sakral masih terjaga.

2. Hubungan antara Pola Ruang dan Hierarki Ruang Dalam teori ruang seringkali kita temukan bahwa pada umumnya tempat ibadah memiliki pola ruang yang memusat terhadap objek penghormatannya. Demikian pula halnya dengan beberapa studi kasus cetiya yang memiliki pola ruang memusat, walaupun cetiya-cetiya tersebut memiliki bentuk beragam dengan skala ruang yang relatif kecil. Misalnya, pada ruang cetiya yang memiliki luas ruang sebesar 4x4 meter dengan pola ruang memusat, tetap memiliki hierarki yang jelas. Dengan demikian dapat dikatakan bahwa pola ruang dan hierarki ruang berbanding lurus.

Cetiya adalah bentuk ruang peribadatan terkecil dalam agama Buddha, sesudah Arama dan Vihara. Cetiya muncul sebagai pengganti simbol penghormatan baru setelah jaman Buddha Gautama mangkat pada tahun 543 Sebelum Masehi di Kusinara, India. Dalam perkembangannya bentuk awal cetiya berupa bangunan monumental pengganti figur Buddha (Dhātucetiya, Paribhogacetiya, Dhammacetiya, Uddesikacetiya). Kini cetiya telah mengalami perubahan bentuk menjadi berbagai bentuk ruang atau bangunan, bukan lagi hadir sebagai pengganti figur Buddha. Fungsinya lebih sebagai tempat ibadah dalam skala kecil diantaranya yaitu berupa ruangan kecil yang dijadikan tempat peribadatan pribadi maupun kelompok tertentu, atau suatu komunitas tertentu, ada pula yang berupa sudut ruangan di sebuah fungsi hunian atau kantor, ruang berupa kamar khusus dalam rumah tinggal, bahkan unit apartemen sewa.

Pergeseran fungsi yang kini terjadi, ternyata tidak berpengaruh terlalu banyak dalam hal penataan pola ruang yang tetap memperlihatkan representasi simbol Buddha dan orientasi ruang yang memusat, serta tetap terjaganya hierarki sebagai ruang ibadah yang privat dan khusuk walaupun dengan elemen pelingkup dan atribut ruang yang berlainan. Dari hasil temuan penelitian tersebut, maka dapat disimpulkan bahwa simbol masih dikenal hingga saat ini namun direpresentasikan berbeda dari konsep awalnya yang berupa tempat suci atau penyimpanan benda suci Buddha. Penamaan yang sama yaitu "cetiya" tetap digunakan, namun secara fungsi sebagai ruang ibadah yang menampung aktivitas penghormatan masih dipertahankan.

\section{Daftar Pustaka}

[1] Ashihara, Yoshinobu, Exterior Design in Architecture, New York: Van Nostrand Reinhold, 1981.

[2] Belia, Anes., Solikhah, Ely, Analisa Alun Alun Kota Tegal 2. Diploma Desain Arsitektur: UNDIP (Tidak dipublikasikan), 2010.

[3] D.K. Chink, Francis, Arsitektur Bentuk, Ruang dan Susunannya, Jakarta: Erlangga, 1973.

[4] Hari, Aditya. 2009. Tapak Landscape - Sistem Sirkulasi : What would you do with this Room, Available at http://vote-mydaily.blogspot.com/2009/10/tapaklanskap-sistem-sirkulasi.html Accessed: 2014-04-09.

[5] Haris, Cryill M, Dictionary of Architecture and Construction, New York: McGraw-Hill Company, 1975. 


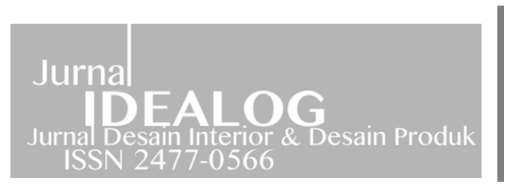

[6] Hutagalung, Dedek. 2010. Pengertian Ruang, Available at http://dedekbaskom.blogspot.com/2010/06/ruang.html Accessed: 2014-04-12.

[7] Laporan Tugas Akhir: Tofani, Logi, Terminal Imbanagara Kabupaten Ciamis. Fakultas Teknik dan Ilmu Komputer, Universitas Komputer Indonesia, 2011.

[8] Neufert, Ernest, Architect's Data. Second. Dialihbahasakan oleh Sjamsu Amril. Jakarta: Erlangga, 1991.

[9] Prabawasari, V.W., Suparman, Agus, Tata Ruang Luar, Jakarta: Gunadharma, 2008.

[10] Rahmah, Nadiya. 2010. Sistem Sirkulasi Tapak: Nadra's Note, Available at http://nadrasnote.blogspot.com/2010/04/sistem-sirkulasi-tapak.html Accessed: 2014-04-10.

[11] Sofyan, Deden Asep. 2010. Jenis-jenis Sirkulasi. Available at http://dedenasepsofyan.blogspot.com/2010/02/jenis-jenis-pola-sirkulasi.html Accessed: 2014-04-08.

[12] Sugono, Dendy, Kamus Besar Bahasa Indonesia, Jakarta: Pusat Bahasa Depdiknas, 2008.

[13] Yadnya, Dharma, Konsep Perancangan Tapak. Disampaikan dalam Perkuliahan Teori \& Metode Perancangan Arsitektur 2, Denpasar: Tidak diterbitkan, 2012. 